\title{
Teksta juridiskās ekspertīzes īpatnības lietās par naida izraisišanu
}

\author{
Ëriks Trels \\ Rīgas Stradiṇa universitāte, Juridiskā fakultāte, Latvija \\ eriks.trels@gmail.com
}

\section{Kopsavilkums}

Saskaṇā ar Kriminālprocesa likuma 34. pantu procesa virzītājs var pieaicināt un ar lēmumu uzdot ekspertīzi veikt personai, kura nav ekspertīžu iestādes eksperts, bet kuras zināšanas un praktiskā pieredze ir pietiekama ekspertīzes izdarīšanai. Veicot ekspertīzes lietās par naida vai nesaticības izraisišanu, kas saistìtas ar personas nacionālo vai etnisko piederību, rasu vai relig̣isko pārliecību (Krimināllikuma 78. pants), vai atkarībā no personas dzimuma, vecuma, invaliditātes vai jebkuru citu pazīmju dẹl (Krimināllikuma 150. pants), pieaicinātajam ekspertam jābūt pietiekamām zināšanām un praktiskai pieredzei tieši šajā jomā, jāprot identificēt, atškịirt un norobežot abos pantos minētās darbības gan vienu no otras, gan arī no citiem Krimināllikumā paredzētajiem noziedzīgajiem nodarījumiem.

Par ekspertiem šādās lietās tika piesaistīti speciālisti no izglīîibas iestādēm (Latvijas Universitātes, Rīgas Stradina universitātes), Tiesībsarga biroja, Valsts valodas ağentūras un neatkarīgām biedrībām (Sabiedriskās politikas centra "Providus" un Latvijas Cilvēktiesību centra). Tomēr, n,emot vērā tiesu prakses neesamỉbu lietās par sociālā naida izraisīšanu, gan tiesību normas piemērotājiem šo lietu izmeklēšanas gaitā, gan arī pieaicinātajiem ekspertiem, veicot teksta juridiskās ekspertīzes, jāsaskaras ar vairākiem problēmjautājumiem.

Atslēgvārdi: naida noziegumi, Krimināllikuma 78. pants, Krimināllikuma 150. pants, teksta juridiskā ekspertīze. 


\section{levads}

2014. gada 25. septembrī tika veikti kārtējie grozījumi Krimināllikumā (turpmāk $\mathrm{KL}$ ), kas pilnveidoja normatīvo regulējumu saistībā ar tā saucamajiem naida noziegumiem [6,22-28], paredzot atbildību par sociālā naida un nesaticības izraisīšanu [11]. Lìdz šim normatīvais regulējums paredzēja atbildību par darbību, kas vērsta uz nacionālā, etniskā, rasu (KL 78. pants) vai religiskā (līdz 2014. gada 29. oktobrim KL 150. pants) naida vai nesaticības izraisǐšanu. Ar veiktajiem grozijumiem jau esošās pazīmes (piederība pie noteiktas rases, etnosa vai tautības un relig̣iskās pārliecības), kas var kḷūt par iemeslu naida noziegumam, tika papildinātas ar šādiem kritērijiem: dzimums, vecums un invaliditāte, turklāt šo uzskaitïjumu veidojot kā nenoslēgtu kritēriju loku, jo atbildība ir paredzēta par darbību, kas vērsta uz naida vai nesaticības izraisǐšanu arī jebkuru citu pazìmju dēl [5, 97-99].

Grozījumi skāruši arī KL 78. pantu "Nacionālā, etniskā un rasu naida izraisīšana", kas skan šādi:

“(1) Par darbību, kas vērsta uz nacionālā, etniskā, rasu vai reliǵiskā naida vai nesaticības izraisīšanu, - soda ar brīvības atṇemšanu uz laiku lìdz trim gadiem vai ar islaicīgu brīvības atñemšanu, vai ar piespiedu darbu, vai ar naudas sodu.

(2) Par tādu pašu darbỉbu, ja to izdarījusi personu grupa vai valsts amatpersona, vai uzṇēmuma (uzṇēmējsabiedrības) vai organizācijas atbildīgs darbinieks vai ja tā izdarìta, izmantojot automatizētu datu apstrādes sistēmu, - soda ar brīīibas atṇemšanu uz laiku līdz pieciem gadiem vai ar īslaicīgu brīvības atṇemšanu, vai ar piespiedu darbu, vai ar naudas sodu.

(3) Par šã panta pirmajā dạ̦ā paredzēto darbību, ja tā saistîta ar vardarbỉbu vai draudiem vai ja to izdarijjusi organizēta grupa, - soda ar brīvības atṇemšanu uz laiku lỉdz desmit gadiem un ar probācijas uzraudzību uz laiku lỉdz trim gadiem vai bez tās." [12]

Savukārt KL 150. pantā "Sociālā naida un nesaticības izraisiš̌ana" noteikts:

“(1) Par darbību, kas vērsta uz naida vai nesaticības izraisiššnu atkarībā no personas dzimuma, vecuma, invaliditātes vai jebkuru citu pazīmju dẹl, ja ar to radīts būtisks kaitējums, - soda ar îslaicīgu brīvības atṇemšanu vai ar piespiedu darbu, vai ar naudas sodu.

(2) Par šā panta pirmajā dạ̦ā paredzēto noziedzīgo nodarījumu, ja to izdarījusi valsts amatpersona vai uzṇēmuma (uzṇēmējsabiedrības) vai organizācijas atbildīgs darbinieks, vai personu grupa vai ja tas izdarīts, izmantojot automatizētu datu apstrādes sistēmu, - soda ar brīvības atṇemšanu uz laiku lỉdz trim gadiem vai ar îslaicīgu brīvības atñemšanu, vai ar piespiedu darbu, vai ar naudas sodu.

(3) Par šā panta pirmajā dạ̦ā paredzēto darbỉbu, ja tã saistīta ar vardarbỉbu vai draudiem vai ja to izdarijusi organizēta grupa, - soda ar brīvības atn̦emšanu uz laiku lïdz četriem gadiem vai ar îslaicīgu brīvības atṇemšanu, vai ar piespiedu darbu, vai ar naudas sodu." [12] 
Veiktie grozījumi nav pretrunā arī Eiropas Drošības un sadarbības organizācijas Demokrātisko institūciju un cilvēktiesību biroja sniegtajai naida nozieguma definīcijai:

A) jebkurš noziedzīgs nodarỉjums, tostarp noziegums pret personu vai īpašumu, kad cietušais, vieta vai nozieguma mērḳis ir izvēlēti pēc to faktiskās vai šḳietamās saiknes, atbalsta, piederības vai dalības grupā, kas definēta B dalāă;

B) grupa var balstīties uz tās locekḷu reālu vai šḳietamu rasi, nacionālo vai etnisko izcelsmi, valodu, ādas krāsu, reliǵiju, dzimumu, vecumu, fizisko vai garīgo invaliditāti, seksuālo orientāciju vai citu līdzīgu pazìmi [28, 11].

Saskaṇā ar Iekšlietu ministrijas Informācijas centra datiem pēdējo piecu gadu laikā pēc KL 78. panta tika uzsākti 67 kriminālprocesi (2011. gadā - 12, 2012. gadā 17, 2013. gadā - 20, 2014. gadā - 8, 2015. gadā - 10) [2]. Statistiskie dati par 2015. gadu liecina arī, ka Ogres novadā ir uzsākts viens kriminālprocess pēc KL 150. panta trešās dal̦as. Analizējot tiesu praksi lietās pēc KL 78. panta, konstatējams, ka galvenais naidīgu izteikumu izplatišanas avots ir internets.

Darba mērḳis - sākt diskusiju par iespējamiem problēmjautājumiem, kas saistīti ar Krimināllikuma 78. un 150. panta piemērošanu.

Materiāls un metodes - temata analīze veikta starpdisciplināri, izmantojot šādas vispārīgās pētniecības metodes: salīdzināšanu un apkopojumu, cēloṇsakarību atklāšanu, analīzi un sintēzi.

\section{Rezultāti un diskusija}

Procesa virzìtājiem, izmeklējot ar naidu un neiecietību saistītos noziegumus, kas tika izdarīti interneta vidē, kā arī pieaicinātiem ekspertiem, veicot teksta juridiskās ekspertīzes, pirmkārt, ir nepieciešams nošḳirt naida noziegumus no aizspriedumiem un stereotipiem.

Aizspriedumi ir kādas nacionālas, etniskas, rasu, reliǵiskas vai sociālas grupas un tās dalībnieku negatīvs vērtējums. Tie ir objektīvi nepamatoti pien̦ēmumi "par kādu cilvēku, cilvēku grupu vai sabiedrības parādību. Aizspriedumu pamatā ir nepareizi vai kḷūdaini vispārinājumi, kā arī strikta un nelokāma attieksme, un to rašanos veicina sociālā distance - grupu, kas atšḳiras pēc sociālā stāvokḷa, tautības, reliǵijas utt. dzīves nošḳirtība" $[1,63]$.

Savukārt stereotipi ir noturīgie aizspriedumi. Latvijas Cilvēktiesību centra darbinieki skaidro, ka stereotipi ir "vispārēji, vienkāršoti, noturīgi priekšstati par dažādām sociālām, arī etniskām grupām ar tām raksturīgām ìpašî̉ām. Stereotipi veidojas cilvēku sociālās izziṇas un sociālo parādību kategorizācijas procesā. Svarīgs stereotipu aspekts ir tāds, ka tie nebalstās uz objektīvu patiesību, bet pamatojas uz diezgan subjektīviem un bieži vien nepārbaudāmiem apgalvojumiem un pieņēmumiem" [1, 13].

Publiskā telpā stereotipi ir visai izplatīit. Pie stereotipiem jāpieskaita, piemēram, uzskati: "visi čigāni ir zaglil" vai "visi musulmaṇi ir teroristi". Pieaicinātajiem ekspertiem, veicot teksta juridiskās ekspertīzes, bieži jāsaskaras ar kḷŭdainiem vispārinājumiem un 
pieṇēmumiem par kādu grupu. Pie aizspriedumiem jāpieskaita, piemēram, uzskati, ka "visi X tautības pārstāvji ir debili" [26]. İstenojot principu "Nedari citam to, ko nevēlies, lai darìtu tev", kā arī lai noskaidrotu, vai analizējamais izteiciens ir aizskarošs, šeit un turpmāk raksta autors piedāvā nezināmo elementu " $X$ " aizvietot ar šì raksta lasītāja tautību vai citu atbilstošu kritēriju.

Veicot teksta juridiskās ekspertīzes, pieaicinātajiem ekspertiem jāatceras, ka aizspriedumi vai naids pret indivīdiem vai sabiedrības grupu etniskās piederības, rases, relig̣ijas, seksuāās orientācijas, valodas, invaliditātes u. c. pazīmju dẹl ir naida noziegumu pamatā $[4,3]$.

Otrkārt, veicot teksta juridiskās ekspertīzes, ir nepieciešams pievērst īpašu uzmanību aicinājumiem veikt prettiesiskas darbỉbas pret kādu nacionālu, etnisku, rasu, relig̣isku vai sociālu grupu. Tas varētu būt aicinājums veikt kādu tīšu darbību ar nolūku pilnīgi vai daḷēji iznīcināt kādu cilvēku grupu kā tādu (pie šādiem izteicieniem pieskaitāms, piemēram, šāds komentārs: "Nāvi [X grupas pārstāvjiem]! Visus krāsnī! Sākot ar zìdainiem un beidzot ar vecāmmātēm! Lai neviens nepaliek!!!" [20]); aicinājums grupas locekḷus nogalināt (piemēram, "Labs [X grupas pārstāvis] - miris [X grupas pārstāvis]" [25]); aicinājums grupas locekḷiem nodarīt miesas bojājumus (piemēram, "Nu ko, ejam sist [X grupas pārstāvjus]" [24]); aicinājums lietot līdzekḷus, kuru mērḳis ir novērst bērnu dzimšanu šādā grupā (piemēram, "[X grupas pārstāvjus] kā sugu vajag kastrēt jau kopš dzimšanas" [24] vai "[X grupas sieviešu kārtas personām vajag iesist] ar kieǵeli pa vēderu, lai nevar reproducēties" [27]), vai aicinājums izdarīt kādas citas prettiesiskas darbības pret šo grupu.

Parasti aicinājums tiek izteikts, izmantojot darbības vārdus pavēles izteiksmē (jeb imperatīvā). Darbības vārds pavēles izteiksmē tiek lietots, ja ar to tiek izteikta pavēle, pamudinājums, aicinājums, lūgums. Tomēr krimināltiesību zinātnieki norāda, ka dažreiz aicinājumi tiek izteikti aizplīvurotā veidā, izmantojot darbības vārdus vēlējuma izteiksmē $[29,69-72]$ vai izmantojot izteicienus "būtu labi, ja", "es vēlètos, lai" u. c. [30, 68-69]. Darbības vārds vēlējuma izteiksmē tiek lietots, ja tiek norādīts uz vēlamu darbỉbu, kas noteiktos apstākḷos var būt iespējama vai neiespējama. No piemēriem ir redzams, ka dažreiz aicinājumi tiek izteikti aizplīvurotā veidā, izmantojot alegorijas (notikumi un parādības tiek atspoguḷotas simboliski, nevis stāstoši), metaforas (viens no mākslinieciskās izteiksmes līdzekḷiem, kas bieži tiek izmantots dzejā) vai retoriskus jautājumus (jautājumus, uz kuriem nav nepieciešama atbilde). "Retoriskajos jautājuma teikumos izsaka apgalvojumu vai noliegumu. Teikumam jautājuma modalitāte tiek pieškirta stilistiskos nolūkos - galvenokārt, lai izceltu kāda apgalvojuma vai nolieguma kategoriskumu." [3, 630] Savukārt par metaforas piemēru var kalpot komentārs, kurā persona pauž uzskatus, ka X grupas pārstāvjus "var izārstēt tikai ar svinu pakausī” [22]. Parasti ar metaforām "lodi pakausī”, "deviniem gramiem pakausī” jeb "svinu pakausī" literatūrā saprot nāves soda piemērošanu civiliedzīvotājiem un karagūstekṇiem, nogalinot viṇus ar šāvienu pakausī. Šādā veidā sodus piemēroja varas pārstāvji PSRS un nacistiskās Vācijas okupācijas laikā (vēlāk šie noziegumi tika kvalificēti kā genocīds, kara noziegumi un noziegumi pret cilvēci). 
Viens no pirmajiem gadījumiem, kad metafora tika izmantota, lai aizplīvurotu naidu kurinošus izteikumus, bija 2007. gada 22. februārī, kad Latvijas antifašistiskās komitejas organizētās diskusijas "Nacisma, neonacisma un ksenofobijas problēmas Latvijā" laikā kāds radikālās organizācijas pārstāvis publiski salīdzināja sev netīkamās tautas ar gangrēnu, kas jānogriež [21]. Izskatot lietu pirmajā instancē, Rìgas apgabaltiesas Krimināllietu tiesas kolēgija 2008. gada 6. martā atzina personu par vainīgu un sodīja ar brīvības atṇemšanu uz vienu gadu, taču, tā kā tai jau bija neizciesta sodāmība, galīgais sods bija noteikts brīvības atṇemšana uz vienu gadu un sešiem mēnešiem. Augstākās tiesas Krimināllietu tiesu palāta apelācijas instancē minēto spriedumu atcēla dạ̦ā par noteikto galīgo sodu un sodija vainīgo ar brīvības atṇemšanu uz diviem gadiem un vienu mēnesi. Izskatot lietu sakarā ar kasācijas sūdzību, Augstākās tiesas Senāta Krimināllietu departaments šo spriedumu atcēla un lietu nosūtīja jaunai iztiesāšanai apelācijas instances tiesai. Tāpat kasācijas instances tiesa grozīja apsūdzētajam piemēroto drošîbas lïdzekli no apcietinājuma uz sūtijumu saṇemšanas adreses paziṇošanu. 2010. gada 22. februārī Augstākās tiesas Krimināllietu tiesu palāta, atkārtoti apelācijas instancē iztiesājot krimināllietu, atcēla pirmās instances tiesas spriedumu, atzina personu par nevainīgu un attaisnoja, jo personai inkriminētajās noziedzīgajās darbībās nav KL 78. panta pirmajā dạ̣a paredzētā noziedzīgā nodarỉjuma sastāva objektīvās puses pazìmju [18]. 2010. gada 21. maijā Augstākās tiesas Senāts pieñēma lēmumu, kas nav pārsūdzams: apelācijas instances tiesas spriedumu atstāt negrozītu, kasācijas sūdzību noraidìt [17]. Pēc šĩs lietas izpētes jākonstatē, ka dažādās tiesās, vērtējot konkrētajā lietā iegūtos pierādījumus, pieṇemti diametrāli pretēji lēmumi, kas savukārt liecina par Eiropas Komisijas pret rasismu un neiecietību ekspertu kritikas pamatotību, jo konsolidētas tiesu prakses trūkums saistībā ar KL 78. panta piemērošanu un kūdīšanas uz naidu šaurā interpretācija traucē piemērot šìs normas [7, 15-16].

Treškārt, pieaicinātajam ekspertam jābūt pietiekamām zināšanām un praktiskai pieredzei, lai noškirtu darbības, par kurām ir paredzēta atbildība KL 78. pantā, no KL 150. pantā minētajām darbībām.

KL 78. panta pirmajā dạ̦ā ietvertais noziedzīgais nodarījums ir klasificēts kā mazāk smags noziegums, turpretĩ otrajā dạ̣a - kā smags noziegums, bet panta trešajā dạ̦ā - kā sevišşi smags noziegums. Salīdzinājumam KL 150. pantā ietvertais noziedzīgais nodarījums panta pirmajā dạ̣ā klasificēts kā kriminālpārkāpums, otrajā dạ̣ā - kā mazāk smags noziegums, bet panta trešajā daḷā - kā smags noziegums.

Tas, ka par KL 78. pantā ietverto darbību paredzētie sodi ir bargāki nekā par KL 150. pantā minēto darbību, rada absurdu situāciju, jo par darbību, kas vērsta uz etniskā naida vai nesaticības izraisīšanu interneta vidē, piemēram, pret krievu tautības pārstāvjiem, bargākais no paredzētajiem sodiem būs brīvības atṇemšana uz laiku lïdz pieciem gadiem, bet par līdzīga rakstura darbību pret nepilson,iem vai pret krievvalodīgajiem kā pret sociālo grupu, kas veidota pēc kopīgās valodas kritērija, - uz laiku līdz trim gadiem. 
Līdzīga situācija izveidosies, kad naids vai nesaticība interneta vidē būs izraisìta pret patvēruma meklētājiem, bēgliem un personām ar alternatīvu statusu vai pret migrantiem, nenorādot šo personu nacionālo, etnisko, rasu vai religisko piederību. Tas nozīmē, ka notiesātajām personām pieškirtie sodi atšķirsies atkarībā no tā, kā attiecīgā komentārā minētās grupas bija nosauktas. Piemēram, par interneta vidē ievietoto izteicienu "Visus bēglus vajag iznīcināt!" draud sods līdz trīs gadiem, bet par izteicieniem "Visus šos melnos bēglus vajag iznìcināt!" vai "Visus šos musulmaṇu bēglus vajag iznīcināt!" - līdz pieciem gadiem.

Minētajos piemēros noziedzīgo nodarījumu raksturs un radītais kaitējums ir lïdzīgs, un, pēc autora domām, likumdevējs nav ievērojis konsekvenci, paredzot atšḳirīgas soda sankcijas par līdzīgiem noziegumiem.

Būtiska problēma ir saistīta ar KL 78. un 150. panta atšḳirīgu institucionālo piekritību. Saskaņā ar Kriminālprocesa likuma 387. pantu "Drošības policijas pilnvarotas amatpersonas izmeklē noziedzīgus nodarījumus, kas izdarīti valsts drošības jomā vai valsts drošības iestādēs, vai citus noziedzīgus nodarījumus savas kompetences ietvaros un gadijjumos, kad izmeklēšanu uzdevis veikt generālprokurors" [13]. KL 78. pants ir ietverts IX nodalāa "Noziegumi pret cilvēci, mieru, kara noziegumi, genocīds", kas ir Drošības policijas piekritībā. Šĩs iestādes piekritībā ir arī KL X nodaḷa "Noziegumi pret valsti”. Savukārt KL 150. pants ir ietverts XIV nodaḷā "Noziedzīgi nodarījumi pret personas pamattiesībām un pamatbrīvībām", kas ir Valsts policijas kompetencē.

Autors uzskata, ka būtu lietderīgi pārcelt pantu, kas paredz atbildību par sociālā naida un nesaticības izraisǐšanu, KL X nodạ̦ā "Noziegumi pret valsti”, lai tas nonāktu Drošības policijas institucionālā piekritībā. Minētā priekšlikuma îstenošana l̦aus uzsvērt, ka sociālā naida un nesaticības izraisǐšana ir apdraudējums valsts drošỉbai, kā arī dos iespēju lietderīgi izmantot Drošỉbas policijas pieredzi šajā jomā un tās rīcībā esošos resursus.

Ceturtkārt, veicot teksta juridiskās ekspertīzes, pieaicinātajam ekspertam ir nepieciešams nošķirt KL 78. un 150. pantā minētās darbības no citiem KL paredzētajiem noziedzīgajiem nodarījumiem. Tā, piemēram, komentāra "Vai vēl neapnika par savu lohokaustu melot? Atkal kompensācijas izsist gatavojaties?... holokausts ir vien židu mits ..." [19] autors publiski noliedz Otrā pasaules kara laikā pret ebreju tautu istenoto genocīdu (KL 74. ${ }^{1}$ pants), bet aicinājums "sarīkot Latvijas Maidanu" [23] ir vērsts uz valsts varas gāšanu (KL 81. pants), savukārt aicinājums "izveidot Latgales tautas repub$l i k u$ ” ir vērsts uz Latvijas Republikas teritoriālās vienotības graušanu (KL 83. pants).

Pieaicinātajam ekspertam dažreiz jāsaskaras ar noziedzīgā nodarījuma daudzpusību, kad ekspertīzei pakḷautajā komentārā iekḷautie izteicieni atbilst divu vai vairāku dažādu noziedzīgu nodarījumu sastāvu pazīmēm. Piemēram, teikumā "Žēl, ka holokausts ir vien žīdu mìts... Jūs nedrīkstat eksistēt uz šis planētas" [19] personas darbībā vienlaikus saskatāma gan Otrā pasaules kara laikā pret ebreju tautu īstenotā genocīda publiskā noliegšana (KL 74. ${ }^{1}$ pants), gan aicinājumi pilnīgi iznīcināt ebreju tautības pārstāvju grupu kā tādu (KL 78. pants). 
Un, piektkārt, pieaicinātajam ekspertam ir nepieciešams izvērtēt ekspertīzei nodotos izteikumus vārda brīvības nodrošināšanas kontekstā. Veicot teksta juridiskās ekspertīzes, ekspertam ir jāatceras, ka vārda brīvība ir attiecināma ne tikai uz "informāciju" vai "idejām", kas tiek uztvertas labvēlīgi vai neitrāli, bet arī uz tām, kas apvaino, šokē vai uztrauc kādu sabiedrības daḷu [16]. Diskutablās informācijas klāstā ietilpst arī jautājumi par vēsturisko notikumu atšḳirīgu interpretāciju, kas varētu aizskart kā vēsturisku notikumu dalībniekus, tā arī viṇu radiniekus un citas iesaistītās personas [15].

Vienlaikus jāuzsver, ka ārpus vārda brīvības robežām paliek vēsturisko notikumu interpretācija, kas saistīta ar

\footnotetext{
"īstenotā genocīda, nozieguma pret cilvēci, nozieguma pret mieru vai kara nozieguma, tai skaitā PSRS vai nacistiskās Vācijas īstenotā genocīda, nozieguma pret cilvēci, nozieguma pret mieru vai kara nozieguma pret Latvijas Republiku un tās iedzīvotājiem, publisku slavināšanu, noliegšanu, attaisnošanu vai rupju noniecināšanu" (KL 74. ${ }^{1}$ pants).
}

Latvijas Republikas Satversmes 100. pants, 1950. gada 4. novembra Eiropas cilvēku tiesību un pamatbrīvību aizsardzības konvencijas 10. pants un ANO 1966. gada 16. decembra Starptautiskā pakta par pilsoṇu un politiskajām tiesībām 19. pants garantē tiesības uz vārda brīiību. Tomēr gadījumos, kad tekstā ir izplatīti uzskati, kas aicina veikt noziedzīgus nodarījumus, tai skaitā ja tie ir vērsti uz nacionālā, etniskā, rasu, religíiskā vai sociālā naida un nesaticības izraisīšanu, šādu uzskatu izplatî̌ana netiek aizsargāta ar šajos normatīvajos aktos ietvertajām tiesībām uz vārda brīvību.

Cilvēku tiesību un pamatbrīvību aizsardzības konvencijas 10. panta 2. punktā noteikts:

“Tā kā šo brīvību īstenošana ir saistīta ar pienākumiem un atbildỉbu, tā var tikt pakḷauta tādām formalitātēm, nosacījumiem, ierobežojumiem vai sodiem, kas paredzēti likumā un nepieciešami demokrātiskā sabiedrībā, lai aizsargātu valsts drošības, teritoriālās vienotības vai sabiedriskās drošības intereses, nepieḷautu nekārtības vai noziegumus, aizsargātu veselību vai morāli, aizsargātu citu cilvēku reputāciju vai tiesības, nepiel̦autu konfidenciālas informācijas izpaušanu vai lai saglabātu tiesas autoritāti un objektivitāti." [9]

Arī Starptautiskā pakta par pilsoṇu un politiskajām tiesībām 19. panta 3. punktā noteikts, ka

"paredzēto tiesību izmantošana uzliek īpašus pienākumus un atbildību. Tāpēc tā var būt pakḷauta zināmiem ierobežojumiem, taču tiem jābūt likumā noteiktiem un nepieciešamiem:

a) citu personu tiesību un reputācijas cienīšanai;

b) nacionālās drošības, sabiedriskās kārtības, sabiedrības veselības vai tikumības aizsardzībai" [8].

Eiropas Cilvēktiesību tiesa ir atzinusi, ka iecietība un visu cilvēku pašcieñas un vienlīdzības ievērošana ir demokrātiskās un plurālistiskās sabiedrības pamats. Ievērojot šo principu, demokrātiskā sabiedrībā ir nepieciešams piemērot sankcijas par jebkādām izteiksmes formām, kas vērstas uz naida un neiecietības izplatǐšanu, izraisī̌̌anu, stimulěšanu un attaisnošanu [14]. 


\section{Secinājumi}

1. Publiskā telpā izplatītie aizspriedumi un stereotipi, kas aizskar cilvēku cieṇu, iziet ārpus Latvijas Republikas Satversmes 100. pantā, 1950. gada 4. novembra Cilvēka tiesību un pamatbrīvību konvencijas 10. pantā un ANO 1976. gada 23. marta "Starptautiskā pakta par pilsoṇu un politiskajām tiesībām" 19. pantā noteiktajām tiesībām uz vārda brīvību. Kaut arī aizspriedumi un stereotipi parasti nav vērtējami kā uzskati, kas apzināti vērsti uz nacionālā, etniskā, rasu, religiskā vai sociālā naida vai nesaticības izraisišanu, tie var kḷūt par motīvu šādam noziedzīgam nodarījumam, tāpēc šādu uzskatu izplatīšana nav vēlama.

2. Publiskajā telpā izplatītie uzskati, kas vērsti uz nacionālā, etniskā, rasu, religiskā vai sociālā naida un nesaticības izraisiš̌anu, iziet ārpus Latvijas Republikas Satversmes 100. pantā, 1950. gada 4. novembra Eiropas cilvēku tiesību un pamatbrīvību aizsardzības konvencijas 10. pantā un ANO 1966. gada 16. decembra Starptautiskā pakta par pilsoṇu un politiskajām tiesībām 19. pantā noteiktajām tiesībām uz vārda brīvību.

3. Personas tiesību un pamatbrīvību izmantošanai vai realizēšanai jābalstās uz vienlīdzības pamatiem. Autors uzskata, ka būtu lietderīgi veikt grozījumus Krimināllikumā un pielīdzināt par sociālā naida un nesaticības izraisīšanu (KL 150. pants) paredzētās soda sankcijas sankcijām, kas paredzētas par nacionālā, etniskā un rasu naida izraisǐšanu (KL 78. pants).

4. Būtu lietderīgi arī pārcelt pantu, kas paredz atbildību par sociālā naida un nesaticības izraisīšanu, KL X nodaḷā "Noziegumi pret valsti".

5. Interneta vidē publicētie izteikumi, kas vērsti uz nacionālā, etniskā, rasu, relig̣iskā vai sociālā naida un nesaticības izraisiš̌anu, būs publiski apriori, jo tie ir pieejami neierobežotam interneta lietotāju lokam visā pasaulē. Savukārt divu personu savstarpēji paustie naidīgie uzskati par kādu nacionālu, etnisku, rasu, relig̣isku vai sociālu grupu nav uzskatāmi par publiskiem. Tādējādi aizskaroša un naidīga vēstule, kuru saṇēmis viens adresāts, nerada sūtītājam nekādas sekas, ja vien tajā nav saskatāms kāda cita noziedzīga nodarījuma sastāvs, piemēram, draudi izdarìt slepkavību vai nodarīt smagus miesas bojājumus (KL 132. pants).

6. Tiesību piemērotājam jāpārliecinās, ka konkrētajā situācijā nodarījums ir vērsts pret kādu grupu, nevis pret šìs grupas pārstāvi, pamatojoties tikai uz personisku nepatiku.

7. Tiesību piemērotājam jāatceras, ka dažreiz naidīgie aicinājumi tiek izteikti aizplīvurotā veidā, izmantojot darbības vārdus vēlējuma izteiksmē, izteicienus "būtu labi, ja", "es vēlētos, lai" vai uzdodot retoriskus jautājumus, lai izceltu kāda apgalvojuma vai nolieguma kategoriskumu . Naidīgie teksti tiek slēpti, arī izmantojot mākslinieciskās izteiksmes līdzekḷus - alegorijas, metaforas, epitetus, ironiju, perifrāzi, personifikāciju, salīdzinājumus, simbolus u. c. 
8. Palielinoties patvēruma meklētāju un migrantu daudzumam Eiropā, turpina pieaugt sociālā spriedze arī Latvijā un citur Eiropā, un raksta autors paredz, ka šìs spriedzes rezultātā pieaugs arī lietu skaits par nacionālā, etniskā, rasu, religiskā vai sociālā naida un nesaticības izraisiš̌anu.

\section{Legal Expertise Features of the Text in Cases of Hatred Triggering}

\section{Abstract}

In the Section 34 of the Criminal Procedure Law, it is stated: A person directing the proceedings may invite, and assign with a decision, a person to perform an expertexamination who is not an expert of an expert-examination institution, but whose knowledge and practical experience is sufficient for the performance of the expertexamination. Examining cases of hatred or enmity related to personal or national or ethnic, racial or religious beliefs (Section 78 of the Criminal Law), or according to sex, age, disability or any other features of a person (Section 150 of the criminal Law), an invited expert must have sufficient knowledge and practical experience in this area, be able to identify, distinguish and delimitate actions mentioned in both articles, and other criminal offences provided for in the Criminal Law. As experts in such cases were involved specialists from the educational institutions (The University of Latvia, Riga Stradiňš University), as well as the Ombudsman's Office, the Latvian Language Agency and Non-governmental Organisations (Centre for Public Policy PROVIDUS, The Latvian Centre for Human Rights). However, given the lack of case law in matters of social hatred triggering the law, applicants during the investigations of these cases as well as external experts during text legal expertise, faces several challenges.

Keywords: Hate Crime, Section 78 of the Criminal Law, Section 150 of the Criminal Law, Legal Expertise.

\section{Literatūra}

1. Kolčanovs, B., Zankovska-Odiṇa, S., Zālītis, K. Atšk,irīgs klients daudzveidīgā Latvijā. Rīga: Latvijas Cilvēktiesību centrs, 2010.

2. Kriminālā statistika. Latvijas Republikas Iekšlietu ministrijas Informācijas centrs. Iegūts no: http://www.ic.iem.gov.lv/node/109 [sk. 25.02.2016.].

3. Latviešu literārās valodas vārdnīca. 6. sējums, 2. daḷa. P-R. Rīga: Zinātne, 1987.

4. Naida noziegumi. Rìga: Latvijas Cilvēktiesību centrs, 2008. 
5. Treḷs, Ė. Sociālā naida un nesaticības izraisīšanas kritēriju noteikšana. Starptautiskā zinātniskā konference "Drošỉbas nostiprināšanas aktuālās problēmas: politiskie, sociālie, tiesiskie aspekti”: Programma un tēzes. Rīgā, 2015. gada 23. aprīlī. Rīga: Rīgas Stradiṇa universitāte, 2015. 97.-99. lpp.

6. Treḷs, Ė. Valsts policijas darbs daudznacionālajā sabiedrībā. Zinātniskā monogrāfija. Rīga: P\&K, 2012.

7. Ziņojums par Latviju (ceturtais posms). Strasbūra: Eiropas Komisija pret rasismu un neiecietību, 2012.

8. Starptautiskais pakts par pilsoṇu un politiskajām tiesībām. 16.12.1966. Starptautisks dokuments. Latvijas Vēstnesis, 61 (2826), 23.04.2003. Stājies spēkā 14.07.1992.

9. Cilvēka tiesību un pamatbrīvību aizsardzības konvencija. 04.11.1950. Starptautisks dokuments. Latvijas Vēstnesis, 143/144 (858/859), 13.06.1997. Stājies spēkā 27.06.1997.

10. Latvijas Republikas Satversme. 15.02.1922. Likums. Latvijas Vēstnesis, 43, 01.07.1993. Stājies spēkā 07.11.1922.

11. Grozījumi Krimināllikumā. 25.09.2014. Likums. Latvijas Vēstnesis, 204 (5264), 15.10.2014. Stājies spēkā 29.10.2014.

12. Krimināllikums. 17.06.1998. Likums. Latvijas Vēstnesis, 199/200 (1260/1261), 08.07.1998. Stājies spēkā 01.04.1999.

13. Kriminālprocesa likums. 21.04.2005. Likums. Latvijas Vēstnesis, 74 (3232), 11.05.2005. Stājies spēkā 01.10.2005.

14. Eiropas Cilvēktiesību tiesas 2006. gada 6. jūlija spriedums lietā Erbakans pret Turciju, iesniegums Nr. 59405/00.

15. Eiropas Cilvēktiesību tiesas 1998. gada 23. septembra spriedums lietā Leidjo un Izorni pret Franciju, iesniegums Nr. 24662/94.

16. Eiropas Cilvēktiesību tiesas 1976. gada 7. decembra spriedums lietā Hendisaids pret Apvienoto Karalisti, iesniegums Nr. 5493/72.

17. Latvijas Republikas Augstākās tiesas Senāta Krimināllietu departamenta 2010. gada 21. maija lēmums krimināllietā Nr. 11840001107, SKK-213/2010.

18. Latvijas Republikas Augstākās tiesas Krimināllietu tiesu palātas 2010. gada 22. februāra spriedums krimināllietā Nr. 11840001107, PAK-173/2010.

19. Rīgas apgabaltiesas Krimināllietu tiesu kolēgijas 2011. gada 8. jūnija spriedums krimināllietā Nr. 11840001410, Nr. K04-0184-11/28.

20. Rīgas apgabaltiesas Krimināllietu tiesas kolēgijas 2009. gada 20. oktobra spriedums krimināllietā Nr. 11840003809, K04-399-09/31.

21. Rīgas apgabaltiesas Krimināllietu tiesas kolēgijas 2008. gada 6. marta spriedums krimināllietā Nr. 11840001107, Nr. K04-0145-08/3.

22. Cēsu rajona tiesas 2014. gada 12. maija spriedums krimināllietā Nr. 11840003914, K11-0124-15.

23. Rīgas pilsētas Kurzemes rajona tiesas 2014. gada 17. decembra spriedums krimināllietā Nr. 11840001414, K28-0576-14/6.

24. Rīgas pilsētas Kurzemes rajona tiesas 2014. gada 22. janvāra spriedums krimināllietā Nr. 11840004913, K28-0168-14/2.

25. Rīgas pilsētas Kurzemes rajona tiesas 2012. gada 25. septembra spriedums krimināllietā Nr. 11840004211, K28-0523-12/9. 
26. Rīgas pilsētas Latgales priekšpilsētas tiesas 2013. gada 17. aprīḷa spriedums krimināllietā Nr. 11840000613, K29-1086/13.

27. Valmieras rajona tiesas 2014. gada 7. maija spriedums krimināllietā Nr. 11840003614, K39-0250/15.

28. Hate Crimes in the OSCE Region - Incidents and Responses. Annual Report for 2007. Warsaw: Organisation on Security and Cooperation in Europe, Office for Democratic Institutions and Human Rights, 2008.

29. Shibzuhov, Z. A. Publichnije prizivi k osushestvleniju terroristiceskoj dejatelnosti ili publichnoe opravdanije terorisma. Moskva: Jurlitinform, 2014. (Шибзухов, 3. А. Пубцичные призывы к осуществлению террористической Аеятельности ики публичное оправАание терроризма. Москва: Юрлитинформ, 2014.)

30. Shujskij, A. C. Otvetstvennostj za publicnije prizivi k osushestvleniju terroristiceskoj dejatelnosti ili publichnoe opravdanije terorisma. Aktualnije problemi ugolovnogo i ugolovnoispravitelnogo prava: sbornik nauchnix statej. Red. E. H. Zhelvakov. Moskva: Akademija Generalnoj prokuraturi RF, 2010. (Шуйский, А. С. Ответственность за публичные призывы к осуществлению террористической Аеятельности или пубцичное оправАание терроризма. Актуацьные проблемы уголовного и уголовно-исправительного права: сборник научных статей. РеА. Э. Н. Желваков. Москва: Академия Генерацьной прокуратуры РФ, 2010. С. 65-73.) 